\title{
Using Compost from Urban Solid Waste to Prevent Erosion in Road Embankments
}

\author{
By: Francisco Osorio and Juan de Oña
}

This document is a post-print versión (ie final draft post-refereeing) of the following paper:

Francisco Osorio and Juan de Oña (2006) Using Compost from Urban Solid Waste to Prevent Erosion in Road Embankments. Journal of Environmental Science and Health Part A, 41, 2311-2327.

Direct access to the published version: http://dx.doi.org/10.1080/10934520600873134 


\title{
Using Compost from Urban Solid Waste to Prevent Erosion in Road Embankments
}

\author{
Francisco Osorio $^{1 *}$ and Juan de Oña ${ }^{1}$
}

${ }^{1}$ Department of Civil Engineering, MITA Research Group; University of Granada, Spain

\begin{abstract}
This article describes how compost, a by-product generated by solid waste treatment plants, can be usefully applied to road embankments to prevent erosion.. Our study analyzed this process in terms of the following variables: location and orientation; embankment slope (2); soil and compost characteristics; compost dosage (4); vegetation species (4); plot dimensions; and planting method. The results obtained focus on the vegetation survival rate, plant growth and germination; colonization of other species; cover crop for plots; and erosion estimation. It was found that when greater quantities of compost were added to embankments, soil loss was decreased. The addition of this material also produced a marked increase in plant growth, the survival rate of manually planted vegetation, the colonization of other species, as well as the cover crop. However, we observed that compost seemed to hinder the germination of hydroseeded species, whereas colonizing plants germinated more quickly. The side slope was not found to be a significant factor for manually planted species, but turned out to be crucial for hydroseeded varieties.
\end{abstract}

\footnotetext{
*Address correspondence to Francisco Osorio, Department of Civil Engineering; University of Granada; Campus de Fuentenueva, s/n; 18071; Granada - SPAIN; Phone: 34958249463; Fax: 34958246138; e-mail: fosorio@ugr.es
} 
Key Words: Sustainable development, urban waste, compost, erosion, road embankments.

\section{INTRODUCTION}

Degradation from erosion is one of the main causes of slope instability in road embankments

1]. Of all the various types of erosion that can affect such slopes and their immediate surroundings, water and aeolian erosion are undoubtedly the most important. ${ }^{[2-3]}$.

Factors that influence erosion are climate aggression or erosivity, soil erosionability, topographic relief, embankment slope, length and watershed form, and the natural or planted cover crop. Some of these factors, such as cover crop or side slope, can be modified, but others cannot because they are typical of the construction site. This is the case of the climate and soil characteristics of the area.

Plants or cover crop can protect bank slopes from water or aeolian erosion ${ }^{[4]}$. For example, such vegetation can block and retain water from rainfall, and decrease splash erosion. Moreover, the soil permeability and infiltration rate are greater in soils with plants than in soils without them ${ }^{[5]}$. These effects, along with evapotranspiration, permit the reduction of free water on the soil surface. Slopes are thus protected from surface runoff.

Other effects include the modification of mechanical properties and soil fastening thanks to the roots, which create an intimately linked fiber frame. This fiber frame affords the slope protection from traffic and from being stepped upon since it absorbs outside impact. It also helps to insulate the soil surface, thanks to the creation of a microclimate that reduces temperature and humidity variation. As a result, the natural weathering process is considerably attenuated.

Plants play a very important role in erosion control and side slope stabilization. However, embankments are rarely suitable for plants since the materials used are selected 
primarily for their geotechnical characteristics. Furthermore, when construction sites have an arid climate, revegetation becomes more difficult.

Humans generate a great deal of waste and byproducts. Traditional solutions for waste management such as dumping sites and incineration have recently been criticized for a wide variety of reasons ${ }^{[6-7]}$. Not surprisingly, waste management measures are now subject to the regulations in EU directives, and recycling solutions have been proposed.

Various waste products have been analyzed and studied, and some have been found to be useful in engineering projects ${ }^{[8-9-10]}$ : Examples of such products are road building wastes (materials from road surface layers, quarry oversize, and mineral dust of bituminous mixture factories); industrial wastes (thermal power station ashes, iron and steel industry ashes and mine wastes mainly from coal); urban wastes (urban incinerator ashes, used tires, demolition wastes, used engine oils, waste plastic and glass); and organic waste (vegetable waters from olive oil production).

Sludge and compost are generated in the lines of wastewater treatment plants and recycling and composting plants all over the world, but in many countries these products are not reused. However, in the USA compost has occasionallybeen used in road construction to reduce runoff and erosion ${ }^{[3-11-12-13]}$.

Although erosion in road embankments and urban waste management at first seem to be two separate issues, this is not the case. When the fertilizing capacity of byproducts ${ }^{[14-15-16-}$ 17-18] and the need to improve the agronomic properties of highway embankments are considered in the same context, their relation becomes evident since each can offer a partial solution for the other. In other words, fertilization from urban waste can facilitate the growth of a cover crop, which in turn reduces erosion. Therefore, road building companies are potential users of urban waste management products. ${ }^{[9-19]}$. 
The research described in this article shows how compost can be used to enhance road embankment revegetation. Our objectives were: (1) to assess plant growth; (2) to study the influence of design parameters on embankments with a view to examining how they affect decisions regarding revegetation; (3) to ascertain the degree of soil fixation and the consequent reduction of erosion.

\section{MATERIALS AND METHODS}

The subsequent sections describe the different variables in our experiment:

\section{Location and Orientation}

Our research study was carried out in a semi-arid environment with high climate erosivity (little but intense rainfall and limited vegetation) where erosion has an important impact. The area studied was an embankment of the Waste Recycling and Composting Plant of Gádor in Almería, a province in southern Spain. Apart from its southern orientation, this location had the advantage of having very little traffic, and a controlled access.

As described by Rueda ${ }^{[20]}$, this region of Almería has a typically dry Mediterranean climate. The average annual precipitation is $219 \mathrm{~mm}$, most of which occurs in winter, autumn and at the beginning of spring. Winds are primarily west-southwest, and come from the coastal area, though most of the terrain is protected by the Gádor mountain range. East winds are also frequent, especially in summer, when it is extremely hot. However, there are also north winds in this area that can produce temperatures as low as $0^{\circ} \mathrm{C}$ during the coldest winter months. The maximum and minimum temperatures registered during our study were $39.5^{\circ} \mathrm{C}$ and $3.6^{\circ} \mathrm{C}$, with an average relative humidity of $65.9 \%$ (Fig.1). Maximum and minimum temperatures over the last 63 years for the same area were $42^{\circ} \mathrm{C}$ and $0.2^{\circ} \mathrm{C}$, with a relative 
humidity of $73 \%{ }^{[20-21]}$.

(FIGURE 1)

\section{Embankments Slopes}

Due to geotechnical factors, the standard slope ratios for road embankments are 3:2 and 2:1. The first ratio fulfills the security requirements for a great variety of soil types, and reduces the total surface occupation as well as the final cubage of earth to be removed. The second fulfills security requirements for loose unconnected materials with very little internal friction, or is used for environment integration reasons. Tests were carried out on both slope types to analyze their possible influence on the results obtained in our experiment.

\section{Soil and compost characteristics}

The source of the material used in the embankments was an excavation that was made when the waste plant dumps were under construction. The compost was derived from urban solids without any separation. Complete analyses of both materials were made to assess their fertilizing capacity. It was also necessary to ascertain their heavy metal content, and to verify that their microbiological parameters did not exceed the threshold established by the law.

The soil was found to be suitable for use in the embankment core, and in accordance with current Spanish law ${ }^{[22]}$. However, its agronomic characteristics were very limited as can be observed in the percentage of organic matter $(0.32 \%)$ and humic extract $(0.06 \%)$ in the soil samples.

As for the compost, the samples analyzed showed no traces of salmonella or clostridium perfringens. The microbiological parameters of the compost were thus lower than the maximum values established in the draft of the $2^{\text {nd }}$ EU Directive regarding the biological 
treatment of biowaste. Current Spanish legislation ${ }^{[23]}$ establishes no limits for microbiological parameters in compost.

Special attention was then given to the heavy metal content in both soil and compost. There are currently no regulations regarding the application of compost to road embankments because compost has very rarely been used for this purpose as is evident in the lack of bibliographic references on the subject. . The use of biosolids that most resembles the one in our proposal is as a type of fertilizer ${ }^{[6]}$. Thus, agricultural regulations have been used as a reference, since this domain is closely related to ours ${ }^{[24-25]}$.

Accordingly, Spanish legislation $\left(28^{\text {th }}\right.$ May 1998) regarding fertilizers and related products (transposition of European Directive 76/116/EEC) was considered applicable, as well as the proposal in the $2^{\text {nd }}$ European Directive on the biological treatment of biowaste. Table 1 shows that this directive is less restrictive than current legislation if the compost (with the exception of cadmium) is regarded as as stabilised biowaste,

\section{(TABLE 1)}

As shown in Table 1, the values in our samples are lower than the maximum values in both documents (except in the case of cadmium). These regulations were originally motivated by the pollution produced by alkaline batteries, which were often dumped along with organic wastes. Nevertheless, it should be observed that these are limits for the agricultural use of compost. The limitations in these draft directives refer to microbiological parameters, and are more restrictive than the requirements in current regulations.

\section{Compost dosages}

A total of 32 plots were used for the experiment. In other words, four series of four plots were used for each side slope type (3:2 and 2:1). Each of the four series had a different compost 
dosage: $0,40,60$ and $80 \mathrm{Mg} / \mathrm{Ha}$. These dosages are typically used in agriculture ${ }^{[18-26]}$, and are in accordance with the values found in other research on compost application.

\section{Species Selection}

Autochthonous species of local plants were selected to plant on the slopes. Near the Gádor waste plant, there were many species of wild plants that had proven to be very resistant under adverse conditions. Several species were selected with a view to analyzing their growth capacity and to testing different planting methods. The species selected were esparto (Stipa tenaccisima), thyme (Thymus capitatus), genista (Genista umbellata) and broom (Retama monosperma).

\section{Experiment Plot Dimensions}

Each plot had a width of $4 \mathrm{~m}$ at road level, and a length of $5 \mathrm{~m}$ in the direction of the maximum slope of the embankment. This parameter was in consonance with the species size, and the dimensions of the plot were optimal for our experiment

\section{Planting Characteristics}

Depending on the species, two different planting methods were used: hydroseeding $\dagger$ for esparto and thyme, and manual planting for genista and broom.

In the case of hydroseeding, the planting dosage was $2.5 \mathrm{~g} / \mathrm{m} 2$ for each species, and the seeds were shelled before they were planted. The total quantity of seed used was $1,600 \mathrm{~g}$, which was the amount required for four series of eight plots, each with a surface area of

\footnotetext{
${ }^{\dagger}$ Hydroseeding typically consists of applying a mixture of wood fiber, seed, fertilizer, and stabilizing emulsion with hydromulch equipment, to temporarily protect exposed soils from erosion by water and wind.
} 
$20 \mathrm{~m} 2$.

In the case of manual planting, the planting frame was $1 \mathrm{~m} \times 1 \mathrm{~m}$, and planting was triangular. None of the plants had another plant of the same species next to it. Twenty plants (ten of each species) were planted in each plot. The total number of plants was 320 units of genista and 320 units of broom.

\section{Plots and planting method}

The planting areas were then prepared. On the lower part of the embankment four series of four plots were laid out on a 2:1 side slope. A space of $20 \mathrm{~m}$ was then left as a soft transition area on the side slope, and four series of four plots were laid out on a 3:2 side slope. In order to prevent water outside the area of the slope from affecting the experiment, a ditch with a small earth ridge was dug on top of the slope. Once the plots were finished, compost was applied manually. This compost was easily distributed because it is a granular material lacking cohesion and loose when poured.

As previously mentioned, two species were planted manually, whereas two others were planted with hydromulch equipment. Since manual planting required stepping on the embankment slope, broom and genista were planted first, and esparto and thyme were hydroseeded afterwards. The only maintenance was irrigation during the first three weeks after planting the seeds.

\section{Process monitoring and parameter control}

The parameters measured during research were the following:

- Plant survival rate. The survival rate (percentage of living plants) of the two species that had been planted manually was recorded weekly. 
- Plant growth. The growth rate of the two species that had been planted manually was recorded weekly.

- Plant germination. Every two weeks, the number of germinated plants per $\mathrm{m}^{2}$ was counted in the case of thyme and esparto.

- Colonization by other species. Each month colonizing plants per $\mathrm{m}^{2}$ were counted. (These were plant species that had not been planted as part of our experiment and that were in the process of developing without control).

- Cover crop per plot. The cover crop was measured by taking a digital picture of each of the plots.

- Erosion estimation. Erosion was estimated by using the Universal Soil Loss Equation

[27]. This equation was chosen because it is the basis for other more recent equations, and also because it is regarded as one of the most accurate ways of calculating erosion. Various national and international organisms (EU, UNESCO, ICONA, etc.) have used this formula for estimating erosion all over the world ${ }^{[28-29]}$.

- Sampling and analysis for soil and compost examination. The sampling and analysis of the most relevant parameters were carried out according to the most recent CEN standards (European Committee for Standardization) at the date and time of our research. When CEN standards were not available, ISO, international or national standards were applied. The Spanish national standards used were UNE and NLT, which in many cases were transpositions of European standards.

\section{RESULTS AND DISCUSSION}

From the moment planting occurred, the plant species were closely monitored. This section presents and discusses the final results of our study. Tables 3 and 4 at the end of the section 
show the statistical values obtained. These tables contain the average values and the statistical signficance of the slope type and compost dosage parameters.

The genista survival rate was not as high as the broom survival rate, which showed higher values (Fig.2). Average survival rates for genista were $54.38 \%$ for 2:1 side slopes and $58.75 \%$ for $3: 2$ side slopes, while broom showed average survival rates of $81.25 \%$ for $2: 1$ side slopes and $80.63 \%$ for $3: 2$ slopes. The slope type and compost dosage were not statistically significant and were found to have no effect on the survival rates of either plant species.

\section{(FIGURE 2)}

Figure 3 shows the growth rate of both species. In this case, it was found that the growth rate was slightly higher for broom than for genista. Indeed, average growth rates for genista were $47.94 \%$ for $2: 1$ side slopes and $46.83 \%$ for $3: 2$ side slopes, whereas average growth rates for broom were $49.03 \%$ for $2: 1$ side slopes and $52.91 \%$ for $3: 2$ side slopes. Again the type of slope was not statistically significant, and seemed to have no effect on the genista growth rate. However, in the case of broom, the growth rate was statistically higher $(\mathrm{p}<0.05)$ for the 3:2 side slope than for the 2:1 side slope.

\section{(FIGURE 3)}

In the case of genista, the compost dosage was statistically significant $(p<0.05)$, and indicated that the higher the compost dosage, the better the results. This turned out to also be true for broom though with a nuance. The base plot systematically presented worse results than the plots where compost had been applied, but there were no significant statistical differences when plots with different compost dosages were compared with each other. The growth and the survival rate results indicate that broom is more suitable for manual planting than genista.

In the case of hydroseeding, the slope type had an influence on the results. Thyme 
germination was much higher for $2: 1$ side slopes $\left(1.07\right.$ plants $\left./ \mathrm{m}^{2}\right)$ than for $3: 2$ side slopes $\left(0.30\right.$ plants $\left./ \mathrm{m}^{2}\right)$ (Fig.4). In the case of esparto, germination was very low for both slopes, though the 2:1 side slopes showed a better performance with an average value of 0.63 plants $/ \mathrm{m}^{2}$ as opposed to an average value of 0.30 plants $/ \mathrm{m}^{2}$ for $3: 2$ side slope.

Regarding the germination of hydroseeded species (thyme and esparto), slope type was a significant statistical variable $(\mathrm{p}<0.05)$, and turned out to be a more critical parameter for hydroseeded species than compost dosage. Indeed compost dosage was not statistically significant for the germination of esparto. In the case of the germination of thyme, compost dosage was only statistically significant when the base plot $(0 \mathrm{Mg} / \mathrm{Ha}$ of compost $)$ was compared to plots with different compost dosages $(\mathrm{p}<0.05)$. However, when plots with different compost dosages were compared to each other, this variable was not significant

\section{(FIGURE 4)}

Natural colonization by other species was denser for the 3:2 side slope (Fig.5). Moreover, we found that the dependence of colonization on the slope type was relatively strong. The average colonization for 2:1 side slopes was 1.47 plants $/ \mathrm{m}^{2}$. In contrast, for 3:2 side slopes, it was much higher $\left(2.74\right.$ plants $\left./ \mathrm{m}^{2}\right)$. Results for compost dosage were also statistically different $(\mathrm{p}<0.05)$. Table 3 shows that the average colonization values for $0,40,60$ and $80 \mathrm{Mg} / \mathrm{Ha}$ of compost were $0.98,2.27,2.43$ and 2.76 plants $/ \mathrm{m}^{2}$, respectively.

\section{(FIGURE 5)}

The plant species used in the experiment (genista, broom, thyme and esparto) competed with the colonizing species for space, water and nutrients as a cover crop for the plots. This cover crop was denser in the case of 3:2 side slopes than for 2:1 side slopes because of the presence of the previously mentioned colonizing species (Fig.6). For each side slope, plots where the compost was applied presented a denser cover crop than the reference plots (00-21 and 00-32), where no compost was applied. Again, compost dosage was only 
statistically significant when the base plot $(0 \mathrm{Mg} / \mathrm{Ha}$ of compost $)$ was compared to plots with different compost dosages $(\mathrm{p}<0.05)$. However, when plots with different compost dosages were compared to each other, this variable was not significant

\section{(FIGURE 6)}

Soil loss was estimated by means of the Universal Soil Loss Equation ${ }^{[27]}$ :

$$
\mathrm{A}=\mathrm{R} \cdot \mathrm{K} \cdot \mathrm{L} \cdot \mathrm{S} \cdot \mathrm{C} \cdot \mathrm{P}
$$

where A stands for soil loss $(\mathrm{Mg} / \mathrm{Ha} \cdot$ year $)$; R, for the rainfall erosivity index $\left(\mathrm{J} \cdot \mathrm{cm} / \mathrm{m}^{2} \cdot \mathrm{h}\right) ; \mathrm{K}$, for the soil erodibility factor $\left(\mathrm{t} \cdot \mathrm{m}^{2} \cdot \mathrm{h} / \mathrm{Ha} \cdot \mathrm{J} \cdot \mathrm{cm}\right)$; L, for the slope length (non-dimensional); $\mathrm{S}$, for the bank slope factor (non-dimensional); C, for the cropping factor (non-dimensional); $\mathrm{P}$, for the conservation practice factor (non-dimensional).

Several studies have adapted this formula to the particular climate conditions in Spain [30-31]. R, K, L and P have been kept constant for every plot, corresponding to the values $51.10,0.3362,0.41$ and 0.90 , respectively. Differences in the results of erosion can be explained by $\mathrm{S}$, the bank slope factor, and $\mathrm{C}$, the cropping factor, obtained from the percentage of the existing cover crop ${ }^{[28]}$, interpolated in Table 2 , which takes into account the exact value of the cover crop in every plot. S was 18.57 for $2: 1$ slopes and 31.96 in the case of $3: 2$ slopes.

\section{(TABLE 2)}

Figure 7 clearly shows that a denser cover crop lessened soil loss. Consequently, the conclusions regarding soil loss are very similar to those obtained for the cover crop. Indeed, the results for the compost dosages were statistically significant $(\mathrm{p}<0.05)$ when the plots with different compost dosages were compared with the base plots. However, when the plots with different compost dosages were compared to each other, the differences were not statistically significant. Regarding slope type, soil loss was higher for 2:1 side slopes than for 3:2 side 
slopes, and the differences were statistically significant $(\mathrm{p}<0.05)$. The average values were $44.93 \mathrm{t} / \mathrm{Ha} \cdot$ year for 2:1 side slopes and $28.87 \mathrm{t} / \mathrm{Ha} \cdot$ year for 3:2 side slopes.

(FIGURE 7)

Tables 3 and 4 show the statistical results presented in this section:

(TABLE 3)

(TABLE 4)

\section{CONCLUSIONS}

In relation to the agronomic parameters, both types of manually planted species showed satisfactory results:

- The average survival rates for genista and broom survival were $57 \%$ and $81 \%$, respectively.

- Side slope type was not a significant variable in this case.

- Similarly, the addition of compost did not produce better survival rates. However, it was significant for plant growth.

- Again broom showed higher growth rates than genista, with values of 41.55, 55.32, 53.45 and $53.56 \mathrm{~cm}$ for dosages of $0,40,60$ and $80 \mathrm{Mg} / \mathrm{Ha}$. In contrast, the growth rates for genista were $45.17,44.17,47.56$ and $52.62 \mathrm{~cm}$ for dosages of $0,40,60$ and $80 \mathrm{Mg} / \mathrm{Ha}$.

As for the species planted by hydroseeding, different species had different performance levels:

- The germination of thyme and esparto was higher in the base plot than in the plots in which biosolids were applied. However, colonization was much higher in the plots 
with applied compost than in the base plot.

- For both species, plots with 2:1 side slopes presented better results than plots with 3:2 side slopes. In the case of thyme, average germination values of 1.07 and 0.30 plants $/ \mathrm{m}^{2}$ were obtained for slopes of 2:1 and 3:2 respectively. In the case of esparto, average germination values of 0.63 and 0.35 plants $/ \mathrm{m}^{2}$ were obtained for slopes of 2:1 and $3: 2$ respectively.

The cover crop was higher in the plots with 3:2 side slopes, with an average value of $37.44 \%$. In contrast, plots with 2:1 side slopes showed an average value of $19.59 \%$. This was primarily due to the presence of colonizing species.

This research shows that compost application in roads embankments increases cover crop and reduces soil loss. The actual compost dosage was not found to be statistically significant. The base plot (with no compost) showed a soil loss of 53.88t/Ha year. However, in plots where compost was applied, soil loss decreased to $31 \mathrm{t} / \mathrm{Ha} \cdot$ year.

\section{REFERENCES}

1. Grace, J. Erosion control techniques on forest road cutslopes and fillslopes in north Alabama. Transportation Research Record. 1999, 1652, 227-324.

2. Morgan, R. In Erosión y conservación del suelo, Mundi-Prensa, Eds., Madrid, Spain, 1997.

3. Block, D. Controlling erosion from highway projects. Biocycle. 2000, 41(1), 59-62.

4. Arranz, J. Ingeniería de diseño y tecnologías para la mitigación de la erosión en taludes excavados. $1^{a}$ Bienal Española de Ingeniería Geológica y Mineral, Madrid, Spain, 1991.

5. Meyer, L.; Wischmeier, W.; Daniel, W. Erosion, Runoff and revegetation of denuded construction sites. Transaction of the ASAE. 1971, 24(6), 1472-1475. 
6. Cameron, K.; Di, H.; Mclaren, R. Is soil an appropriate dumping ground for our wastes? Australian Journal of Soil Research. 1997, 35(5), 995-1035.

7. Belmonte, A. Reutilización y reciclado de materiales. Experiencia en Andalucía. In the III Congreso Andaluz de Carreteras; Asociación Española de la Carretera, Eds. Madrid, Spain, 2003; 143-185.

8. Vipulanandan, C.; Basheer, M.; O’Neill, M. Recycled materials in embankments, except glass. The Center for Innovative Grouting Materials and Technology Research Report 01351, Preliminary Report, Texas, 1996.

9. Mathur, S.; Soni, S.; Murty, A. Utilization of industrial wastes in low-volume roads. Seventh International Conference on Low-Volume Roads. 1999, 1652, 246-256.

10. Ruiz, A. Experiencias en España con la utilización de residuos y de materiales secundarios en carreteras. Carreteras 2001, 118, 8-25.

11. Storey, B.B.; McFalls, J.A.; Godfrey, S.H. The use of compost and shredded brush on rights-of-way for erosion control. In Research Report. 1352-2F, Texas Transport Institute, College Station, Eds., Texas, 1996.

12. Benick, S.; Wilson, B.; Biesboer, D.; Hansen, B.; Stenlund, D. Performance of erosion control products on a highway embankment. Transactions of the ASAE. 2003, 46 (4), 1113-1119.

13. Persyn, R. ; Glanville, T. ; Richard, T. ; Laflen, J. ; Dixon, P. Environmental effects of applying composted organics to new highway embankments: Part 1. Interrill runoff and erosion. Transactions of the ASAE. 2004, 47 (2), 463-469.

14. Shiralipour, A.; Mcconnell, D.; Smith, W. Uses and benefits of MSW Compost - A review and an assessment. Biomass \& Bioenergy. 1992, 3 (3-4), 267-279.

15. Diaz, I. Aprovechamiento del compost de los residuos sólidos urbanos. Estudio de su 
capacidad fertilizante y del efecto sobre las propiedades físicas, químicas y biológicas del suelo Unpublished $\mathrm{PhD}$ Thesis. Departamento de Químicas y Análisis Agrícola. Universidad Politécnica de Madrid, Spain, 1994.

16. Polo, M. In Uso agrícola de lodos de depuradoras. Consejería de Agricultura y Pesca de la Junta de Andalucía, Eds., Seville, Spain, 1997.

17. Andreadakis; A.; Mamais, D.; Gavalaki, E.; Kampylafka, S. Sludge utilization in agriculture: possibilities and prospects in Greece. Water Science and Technology. 2002, 46(10), 231-238.

18. Amlinger, F.; Gotz, B.; Dreher, P.; Geszti, J.; Weissteiner, C. Nitrogen in biowaste and yard waste compost: dynamics of mobilisation and availability. European Journal of Soil Biology. 2003, 39 (3), 107-116.

19. Aziz, M.; Koe, L. Potential utilization of sewage-sludge. Water Science and Technology. 1990, 22 (12), 277-285.

20. Rueda, F. In Ecosistema de la vega del bajo Andarax. (Ecosystem of the fertile lowland of the Bajo Andarax). Confederación Española de Cajas de Ahorro (Confederation of Spanish Savings Banks), Eds., Madrid, 1987.

21. Las Palmerillas Meteorogical Station. http://www.lasplamerillas.cajamar.es. (Meteorogical daily data from 1976), 2005.

22. Ministerio de Fomento (Ministry of Public Works). PG-3. Pliego de Prescripciones Técnicas Generales para Obras de Carreteras y Puentes (Document of General Technical Prescriptions for Works of Highways and Bridges). First Edition, Madrid, Spain, 1976.

23. Ministerio de Agricultura, Pesca y Alimentación (Ministry of Agriculture, Fishing and Food Products). Orden de 28 de Mayo de 1998 sobre fertilizantes y afines (Order on fertilizer and similar products). (Transposition of European Directive 76/116/EEC), 
Madrid, Spain, 1998.

24. Muchovej, R.; Pacovsky, R. Future directions of by-products and wastes in agriculture. In: Agricultural uses of by-products and wastes, ACS Symposium Series 1997; 668, 1-19.

25. Berger, J.; Boss, A.; Fehrenbach, H.; Knappe, F.; Vogt, R. Assessment of agricultural production from a waste management standpoint. Berichte Uber Landwirtschaft. 2003, 81 (2), 269-301.

26. García, F.; Martínez, J.; Gómez, I.; Mataix, J. Evolución foliar de Macronutrientes (N, P, $\mathrm{K}, \mathrm{Ca}, \mathrm{Mg}, \mathrm{Na}$ ) en olivos fertilizados con lodos de depuradora (Foliation Evolution of Macronutrients (N, P, K, Ca, Mg, Na) in olive trees fertilized with sludges). VI Congreso Hispano-Luso de Fisiología Vegetal (VI Hispanic-Portuguese Congress on Vegetal Phisiology), Seville, Spain, 1999.

27. U.S. Department of Agriculture. Agriculture Handbook 282, 1958.

28. Aguilo, J. In Tratado del medio natural. Causas de destrucción del suelo (Treatise of the natural environment. Causes of destruction of the soil), Tomo I. UPM, CEOTMA, INIA and ICONA, Eds., Madrid, Spain, 1981.

29. United Nations. FAO. Guidelines for Soil Profile Description. Food and Agriculture Organization, $3^{\text {rd }}$ Edition, 1992.

30. Gonzalez, M. La Ecuación Universal de Pérdidas de Suelo. Pasado, presente y futuro (The Universal Soil Loss Equation. Past, Present and Future). Ecología (Ecology). 1991, 5, 7 28.

31. ICONA. Agresividad de la lluvia en España. Valores del Factor R de la Ecuación Universal de Pérdidas de Suelo (Aggressiveness of the rain in Spain. Values of the Factor R in the Universal Soil Loss Equation), Madrid, Spain, 1998. 


\section{FIGURE CAPTIONS}

Figure 1. Main meteorological variables recorded during the research and before the planting

Figure 2. Survival rate of genista and broom

Figure 3. Growth rate of genista and broom

Figure 4. Germination of thyme and esparto

Figure 5. Colonization by other species

Figure 6. Cover crop

Figure 7. Soil Loss 


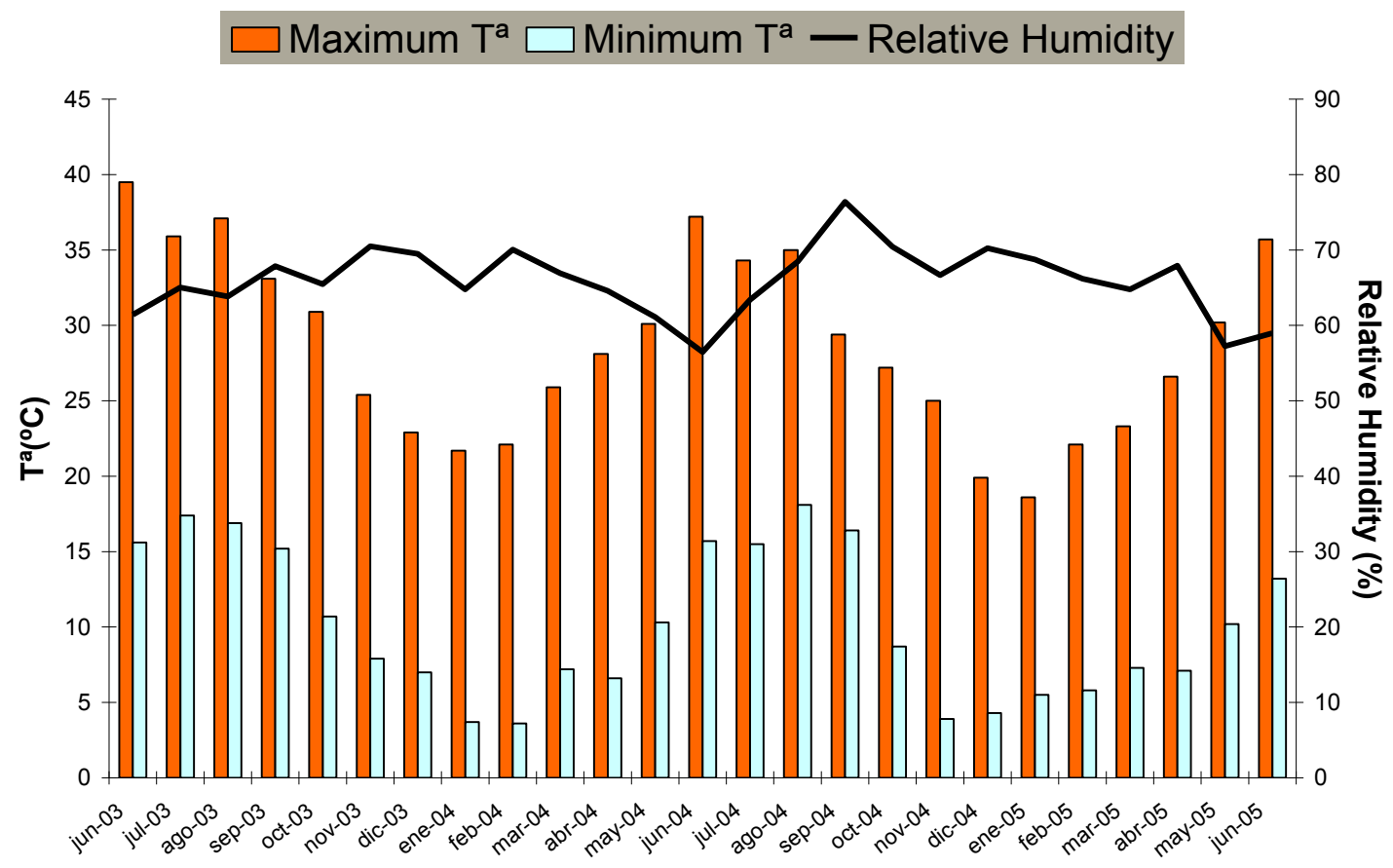

(FIGURE 1) 


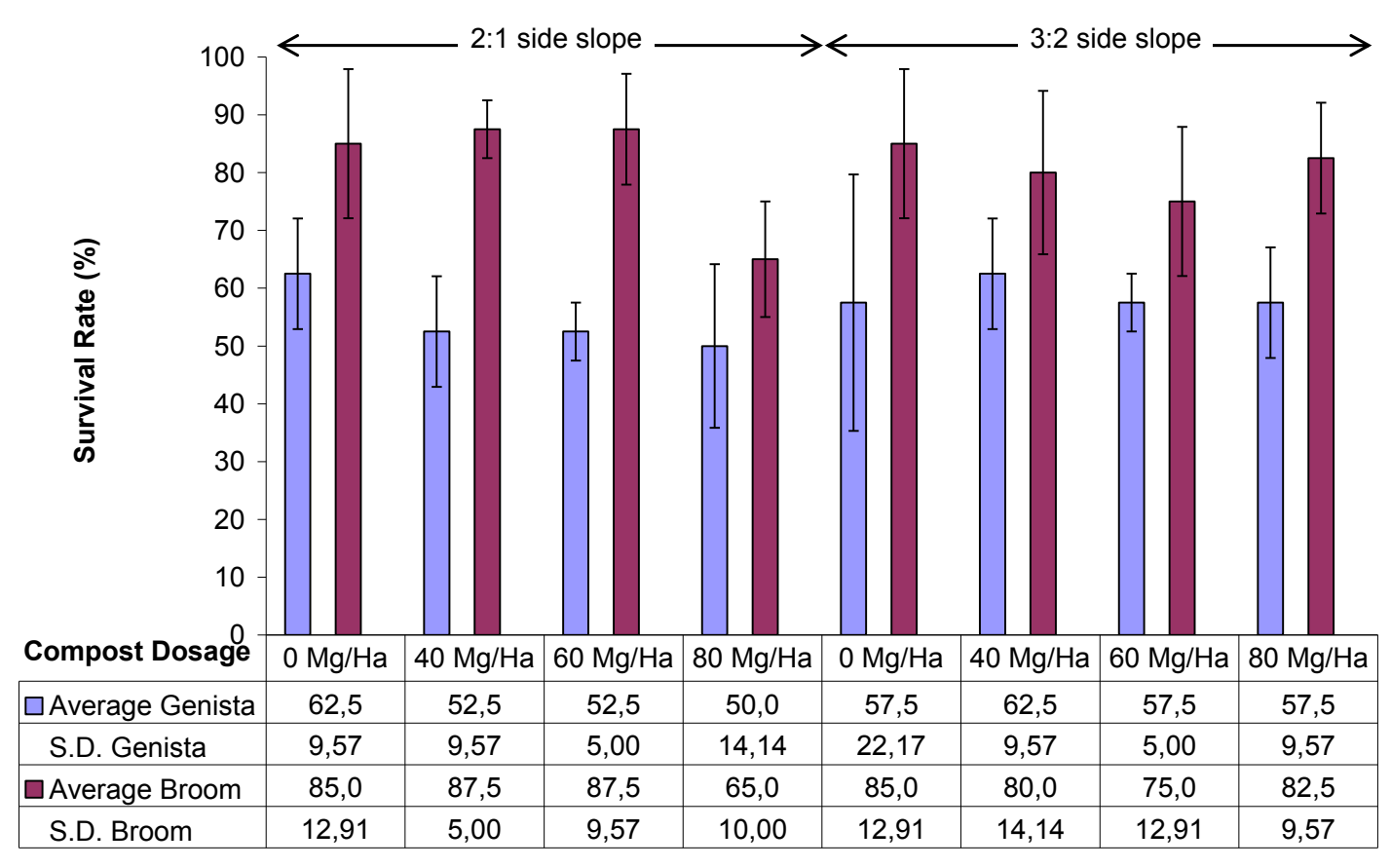

(FIGURE 2) 


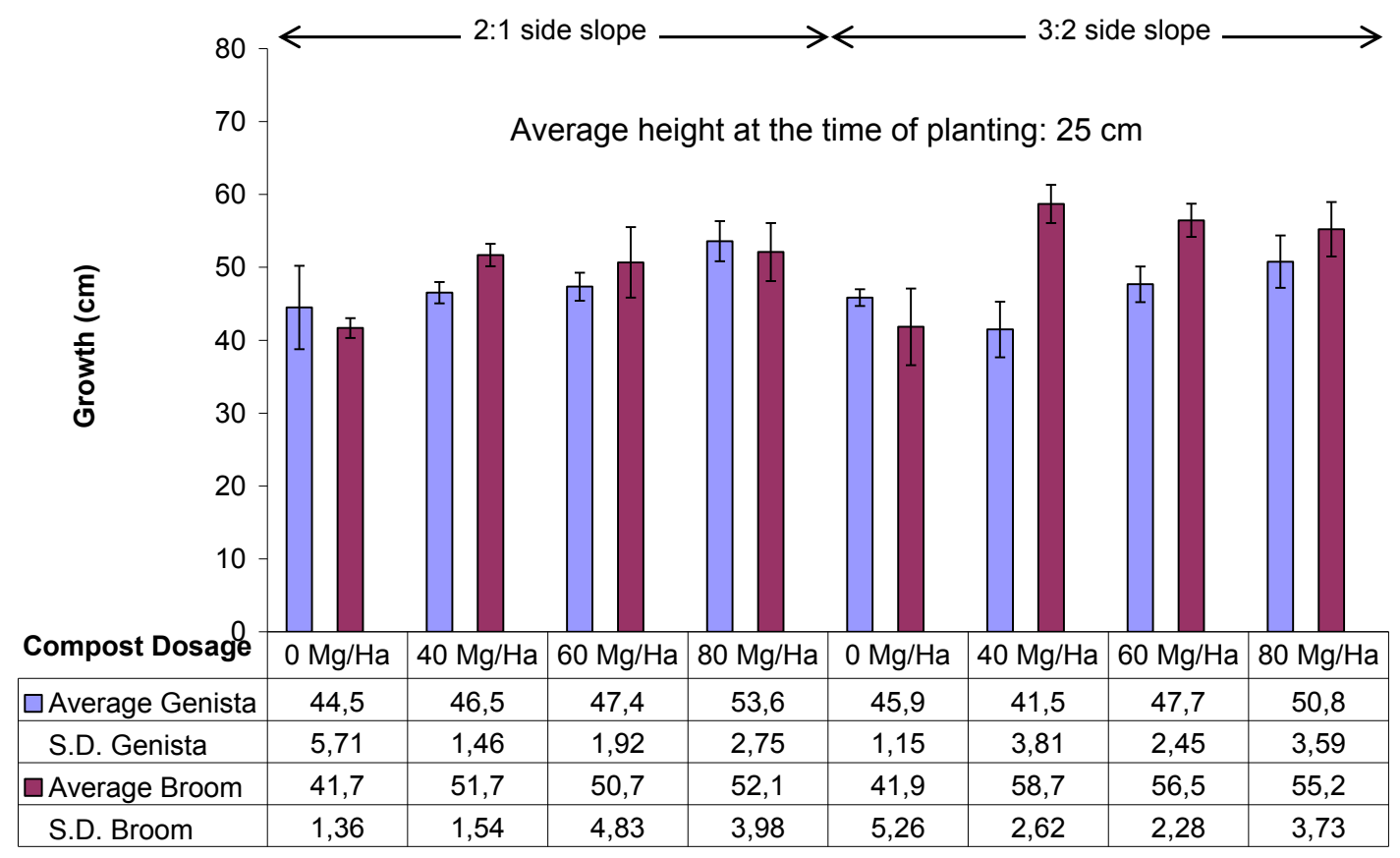

(FIGURE 3) 


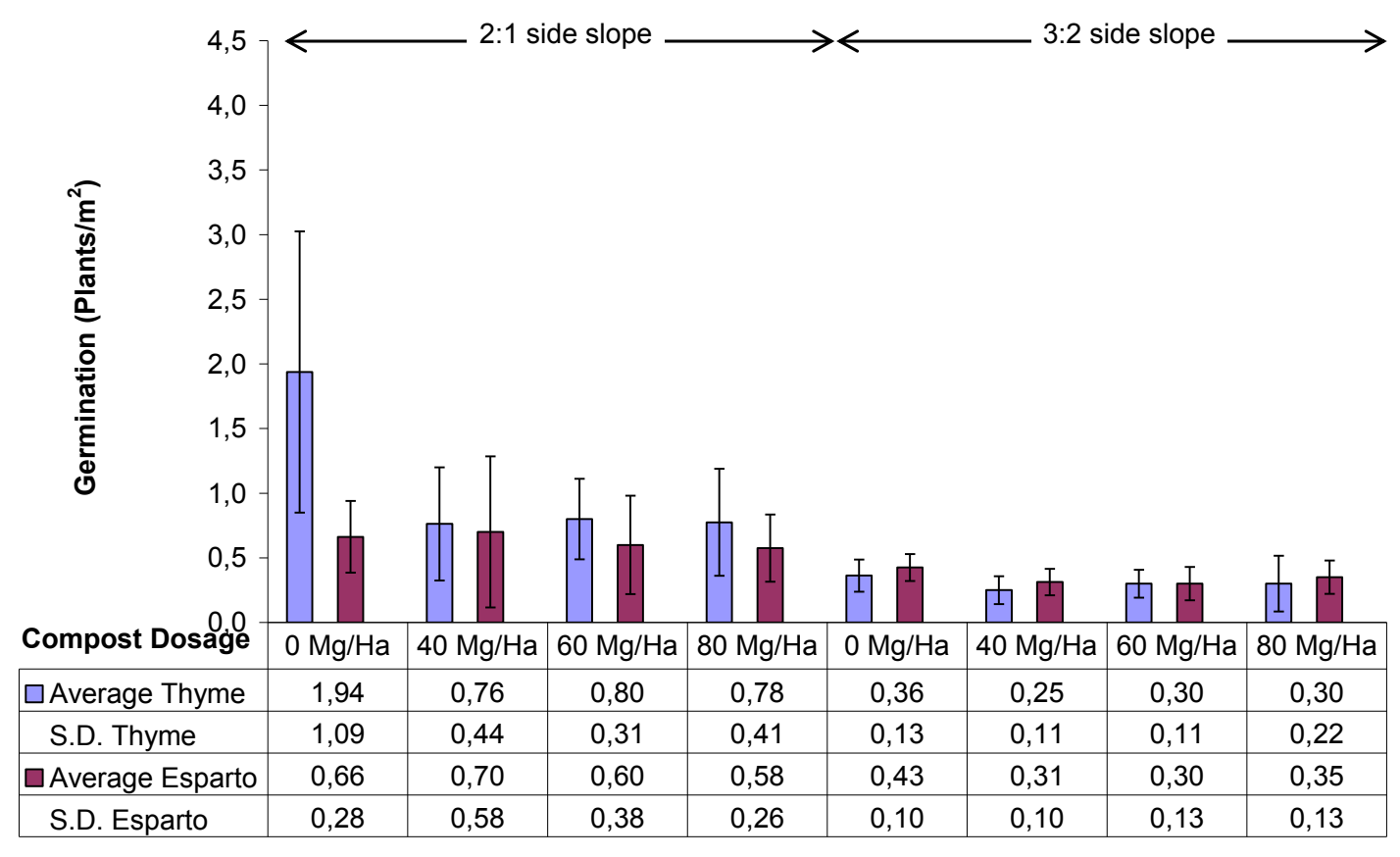

(FIGURE 4) 


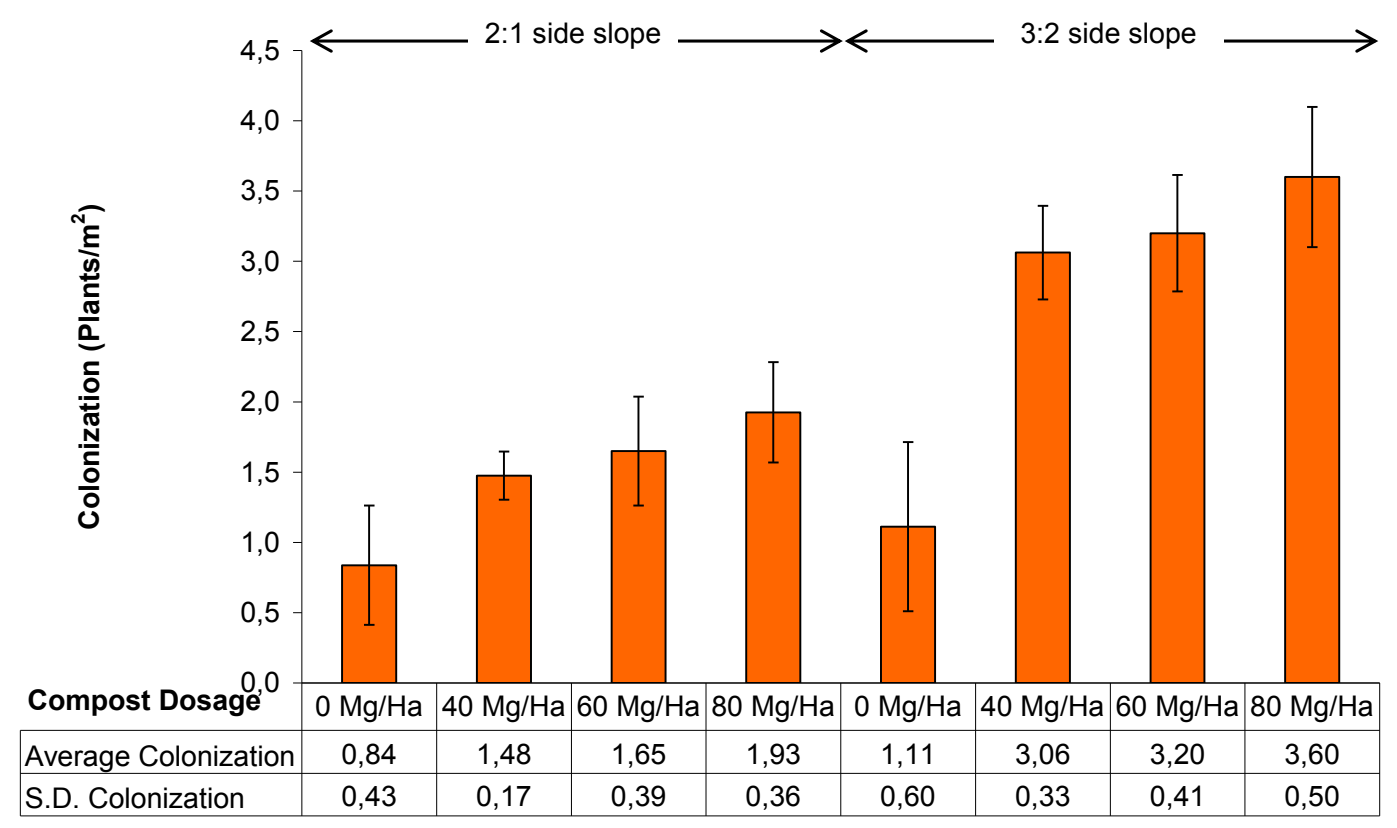

(FIGURE 5) 


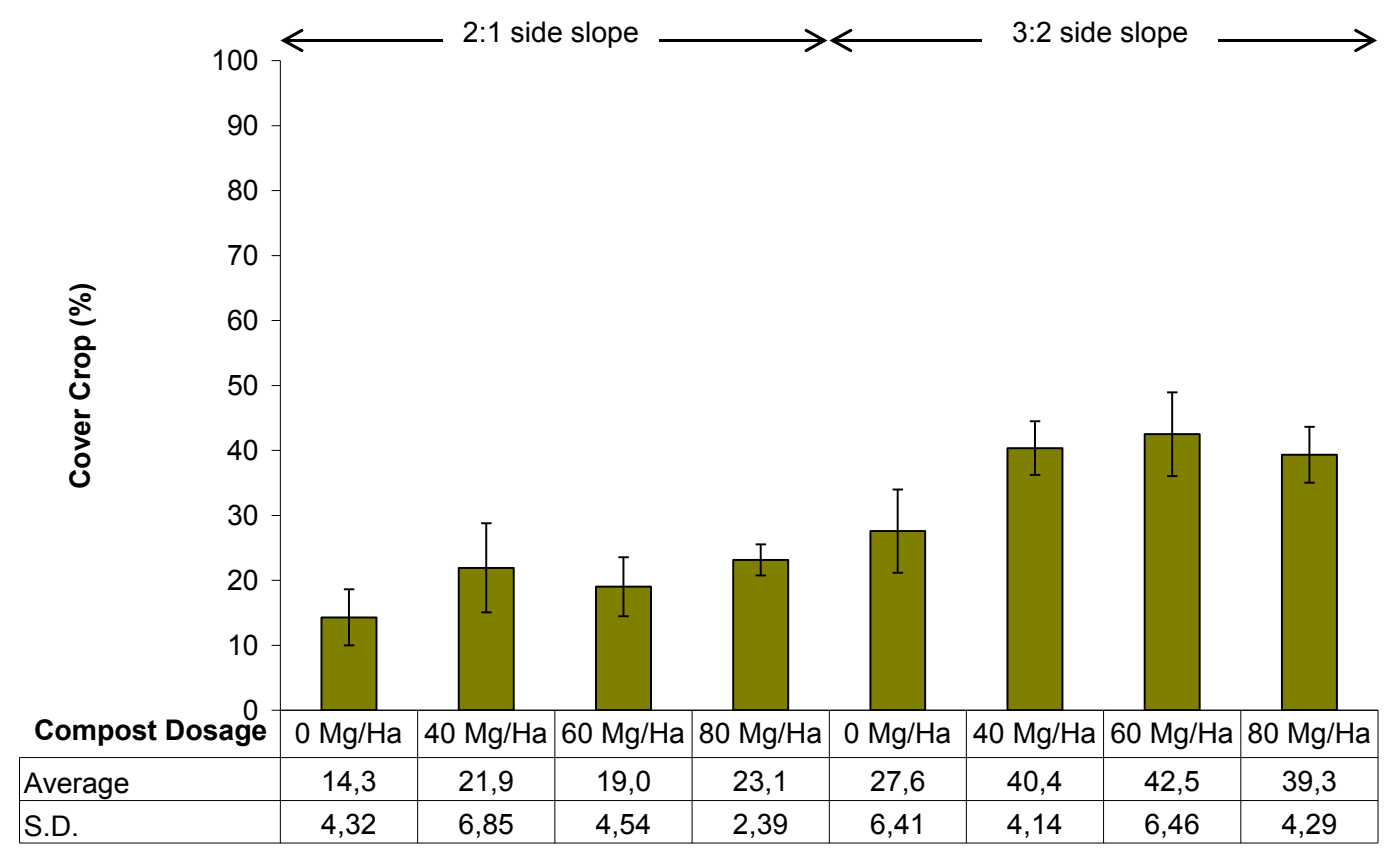

(FIGURE 6) 


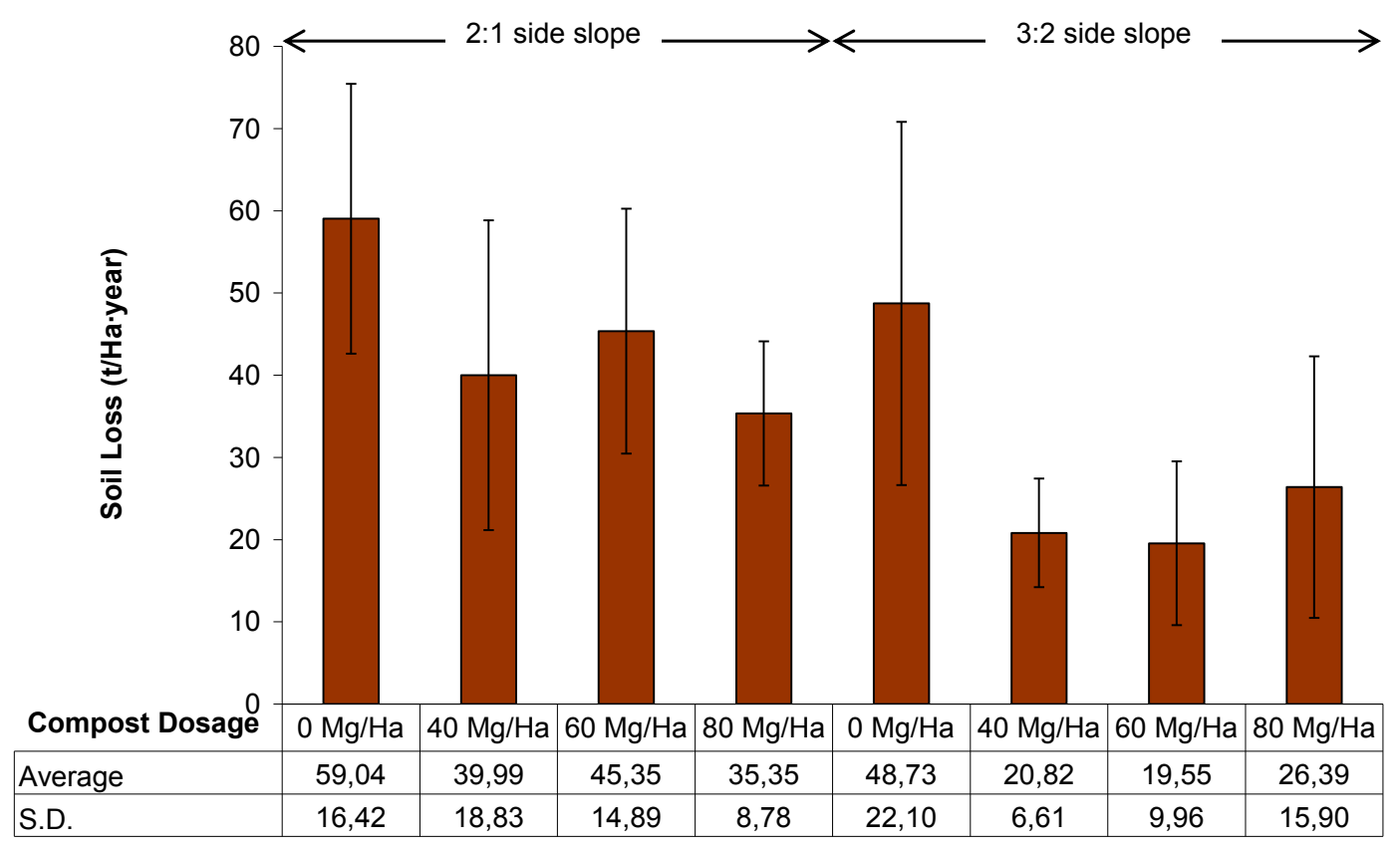

(FIGURE 7) 
Table 1. Heavy metals in soil and compost samples, and maximum values permitted in the agricultural use of compost (European Legislation currently in force, Spanish Law of $28^{\text {th }}$ May, 1998, and $2^{\text {nd }}$ EU Directive Draft)

\begin{tabular}{|c|c|c|c|c|c|c|c|}
\hline Values in $\mathrm{mg} / \mathrm{kg}$ & Cadmium & Cooper & Nickel & Lead & Zinc & \multicolumn{2}{|c|}{ Mercury Chromium } \\
\hline Soil & 2.28 & $<1$ & 2.52 & 9.93 & $<0.5$ & 0.21 & 4.19 \\
\hline Compost & 12.34 & 24.57 & 59.87 & 156.96 & 189.48 & 0.93 & 19.36 \\
\hline $\begin{array}{c}\text { Spanish Order, } 28^{\text {th }} \\
\text { May, } 1998 \\
\text { (Transposed } \\
\text { European } \\
\text { Legislation in force) }\end{array}$ & 10 & 450 & 120 & 300 & 1100 & 7 & 400 \\
\hline $2^{\text {nd }}$ Directive Draft & 5 & 600 & 150 & 500 & 1500 & 5 & 600 \\
\hline
\end{tabular}


Table 2. Cropping factors (C) related to cover crop percentage

\begin{tabular}{cc|cc|cc}
\hline $\begin{array}{c}\text { Cover crop } \\
(\%)\end{array}$ & $\begin{array}{c}\text { Cropping } \\
\text { factor }(\mathrm{C})\end{array}$ & $\begin{array}{c}\text { Cover crop } \\
(\%)\end{array}$ & $\begin{array}{c}\text { Cropping } \\
\text { factor }(\mathrm{C})\end{array}$ & $\begin{array}{c}\text { Cover crop } \\
(\%)\end{array}$ & $\begin{array}{c}\text { Cropping } \\
\text { factor }(\mathrm{C})\end{array}$ \\
\hline 5 & 0.807 & 35 & 0.129 & 65 & 0.017 \\
10 & 0.613 & 40 & 0.086 & 70 & 0.012 \\
15 & 0.466 & 45 & 0.065 & 75 & 0.009 \\
20 & 0.319 & 50 & 0.045 & 80 & 0.006 \\
25 & 0.242 & 55 & 0.034 & 90 & 0.003 \\
30 & 0.166 & 60 & 0.023 & 100 & 0.001 \\
\hline
\end{tabular}


Table 3. Average values and statistical significance of different parameters in relation to compost dosage

\begin{tabular}{|c|c|c|c|c|c|c|c|c|}
\hline Compost dosage $(\mathrm{Mg} / \mathrm{Ha})$ & \multicolumn{2}{|c|}{0} & \multicolumn{2}{|c|}{40} & \multicolumn{2}{|c|}{60} & \multicolumn{2}{|c|}{80} \\
\hline Parameter & Mean & [a] & Mean & [a] & Mean & [a] & Mean & [a] \\
\hline \multirow{2}{*}{ Survival rate of Genista (\%) } & 60,00 & $\mathrm{a}$ & 57,50 & $\mathrm{a}$ & 55,00 & $\mathrm{a}$ & 53,75 & $\mathrm{a}$ \\
\hline & \multicolumn{2}{|c|}{$(\mathrm{N}=8)$} & \multicolumn{2}{|c|}{$(\mathrm{N}=8)$} & \multicolumn{2}{|c|}{$(\mathrm{N}=8)$} & \multicolumn{2}{|c|}{$(\mathrm{N}=8)$} \\
\hline \multirow{2}{*}{ Survival rate of Broom (\%) } & 85,00 & $\mathrm{a}$ & 83,75 & $\mathrm{a}$ & 81,25 & $a$ & 73,75 & $\mathrm{a}$ \\
\hline & \multicolumn{2}{|c|}{$(\mathrm{N}=8)$} & \multicolumn{2}{|c|}{$(\mathrm{N}=8)$} & \multicolumn{2}{|c|}{$(\mathrm{N}=8)$} & \multicolumn{2}{|c|}{$(\mathrm{N}=8)$} \\
\hline \multirow{2}{*}{ Growth of Genista (cm) } & 45,17 & $\mathrm{a}$ & 44,17 & $\mathrm{a}$ & 47,56 & $\mathrm{~b}$ & 52,62 & $\mathrm{C}$ \\
\hline & \multicolumn{2}{|c|}{$(\mathrm{N}=48)$} & \multicolumn{2}{|c|}{$(\mathrm{N}=46)$} & \multicolumn{2}{|c|}{$(\mathrm{N}=44)$} & \multicolumn{2}{|c|}{$(\mathrm{N}=43)$} \\
\hline \multirow{2}{*}{ Growth of Broom (cm) } & 41,55 & $\mathrm{a}$ & 55,32 & $\mathrm{~b}$ & 53,45 & $\mathrm{~b}$ & 53,56 & $\mathrm{~b}$ \\
\hline & \multicolumn{2}{|c|}{$(\mathrm{N}=68)$} & \multicolumn{2}{|c|}{$(\mathrm{N}=67)$} & \multicolumn{2}{|c|}{$(\mathrm{N}=65)$} & \multicolumn{2}{|c|}{$(\mathrm{N}=59)$} \\
\hline \multirow{2}{*}{ Germination of Thyme (plants/m2) } & 1,15 & $a$ & 0,51 & $\mathrm{~b}$ & 0,55 & $\mathrm{~b}$ & 0,54 & $\mathrm{~b}$ \\
\hline & \multicolumn{2}{|c|}{$(\mathrm{N}=8)$} & \multicolumn{2}{|c|}{$(\mathrm{N}=8)$} & \multicolumn{2}{|c|}{$(\mathrm{N}=8)$} & \multicolumn{2}{|c|}{$(\mathrm{N}=8)$} \\
\hline \multirow{2}{*}{ Germination of Esparto (plants/m2) } & 0,54 & $\mathrm{a}$ & 0,51 & $\mathrm{a}$ & 0,45 & $a$ & 0,46 & $\mathrm{a}$ \\
\hline & \multicolumn{2}{|c|}{$(\mathrm{N}=8)$} & \multicolumn{2}{|c|}{$(\mathrm{N}=8)$} & \multicolumn{2}{|c|}{$(\mathrm{N}=8)$} & \multicolumn{2}{|c|}{$(\mathrm{N}=8)$} \\
\hline \multirow{2}{*}{ Colonization (plants/m2) } & 0,98 & $\mathrm{a}$ & 2,27 & $\mathrm{~b}$ & 2,43 & $\mathrm{~b}, \mathrm{c}$ & 2,76 & $\mathrm{C}$ \\
\hline & $(\mathrm{N}=$ & & $(\mathrm{N}=$ & & $(\mathrm{N}=$ & & $(\mathrm{N}=$ & \\
\hline Cover cron (\%) & 20,94 & $a$ & 31,14 & $\mathrm{~b}$ & 30,75 & $\mathrm{~b}$ & 31,24 & $\mathrm{~b}$ \\
\hline Cover crop (\%) & $(\mathrm{N}=$ & & $(\mathrm{N}=$ & & $(\mathrm{N}=$ & & $(\mathrm{N}=$ & \\
\hline 'Ha.vear) & 53,88 & $a$ & 30,41 & $b$ & 32,45 & $\mathrm{~b}$ & 30,87 & $b$ \\
\hline soll ioss ("/na'year) & $(\mathrm{N}=$ & & $(\mathrm{N}=$ & & $(\mathrm{N}=$ & & $(\mathrm{N}=$ & \\
\hline
\end{tabular}

[a] Means followed by different letters within the same row are significantly different $(p<0.05)$ 
Table 4. Average values and statistical significance of different parameters in relation to the slope type

\begin{tabular}{|c|c|c|c|c|}
\hline Sideslope & \multicolumn{2}{|c|}{$2: 1$} & \multicolumn{2}{|c|}{$3: 2$} \\
\hline Parameter & Mean & [a] & Mean & [a] \\
\hline \multirow{2}{*}{ Survival rate of Genista (\%) } & 54,38 & $a$ & 58,75 & $\mathrm{a}$ \\
\hline & \multicolumn{2}{|c|}{$(\mathrm{N}=16)$} & \multicolumn{2}{|c|}{$(\mathrm{N}=16)$} \\
\hline \multirow{2}{*}{ Survival rate of Broom (\%) } & 81,25 & $a$ & 80,63 & $a$ \\
\hline & \multicolumn{2}{|c|}{$(\mathrm{N}=16)$} & \multicolumn{2}{|c|}{$(\mathrm{N}=16)$} \\
\hline \multirow{2}{*}{ Growth of Genista (cm) } & 47,94 & $a$ & 46,83 & $\mathrm{a}$ \\
\hline & \multicolumn{2}{|c|}{$(\mathrm{N}=87)$} & \multicolumn{2}{|c|}{$(\mathrm{N}=94)$} \\
\hline \multirow{2}{*}{ Growth of Broom $(\mathrm{cm})$} & 49,03 & $\mathrm{a}$ & 52,91 & $\mathrm{~b}$ \\
\hline & \multicolumn{2}{|c|}{$(\mathrm{N}=130)$} & \multicolumn{2}{|c|}{$(\mathrm{N}=129)$} \\
\hline \multirow{2}{*}{ Germination of Thyme (plants/m2) } & 1,07 & $\mathrm{a}$ & 0,30 & $\mathrm{~b}$ \\
\hline & \multicolumn{2}{|c|}{$(\mathrm{N}=16)$} & \multicolumn{2}{|c|}{$(\mathrm{N}=16)$} \\
\hline \multirow{2}{*}{ Germination of Esparto (plants/m2) } & 0,63 & $\mathrm{a}$ & 0,35 & $\mathrm{~b}$ \\
\hline & \multicolumn{2}{|c|}{$(\mathrm{N}=16)$} & \multicolumn{2}{|c|}{$(\mathrm{N}=16)$} \\
\hline \multirow{2}{*}{ Colonization (plants/m2) } & 1,47 & $\mathrm{a}$ & 2,74 & $\mathrm{~b}$ \\
\hline & \multicolumn{2}{|c|}{$(\mathrm{N}=16)$} & \multicolumn{2}{|c|}{$(\mathrm{N}=16)$} \\
\hline \multirow{2}{*}{ Cover crop (\%) } & 19,59 & $\mathrm{a}$ & 37,44 & $\mathrm{~b}$ \\
\hline & \multicolumn{2}{|c|}{$(\mathrm{N}=16)$} & \multicolumn{2}{|c|}{$(\mathrm{N}=16)$} \\
\hline \multirow{2}{*}{ Soil loss (t/Ha·year) } & 44,93 & $\mathrm{a}$ & 28,87 & $\mathrm{~b}$ \\
\hline & \multicolumn{2}{|c|}{$(\mathrm{N}=16)$} & \multicolumn{2}{|c|}{$(\mathrm{N}=16)$} \\
\hline
\end{tabular}

[a] Means followed by different letters within the same row are significantly different $(p<0.05)$ 